\title{
Settlers and Squatters: The Production of Social Inequalities in the Peruvian Desert
}

\author{
Astrid B. Stensrud
}

\section{INTRODUCTION}

The Majes Irrigation Project (MIP) in southern Peru has transformed 15,800 hectares of previously unoccupied desert into fertile and productive land. MIP was constructed shortly after the land reform in the 1970s, in a time when progress and equality were on the political agenda. The first settler farmers, who arrived in 1983, are celebrated as strong pioneering men that started from zero and made progress through hard work. One of the goals in MIP, as it developed in the 1980s and 1990s, was to transform farmers into entrepreneurs that would compete on the global market. More than 30 years later, and after the most radical and quickest programme of neoliberal structural adjustment in Latin America, many of the first settlers have lost their farms or are struggling with debt. In the same period, Majes and its main urban centre Villa El Pedregal, has evolved into a hub of business and work and has become known as 'a place of opportunities' (un lugar de oportunidades) with a booming economy. During the last decade, thousands of people have migrated from the poor rural highlands in search of work or informal business in Majes, and these new migrants settle in the desert surrounding the irrigated areas.

A.B. Stensrud $(\bowtie)$

University of Oslo, Oslo, Norway

(C) The Author(s) 2018

M. Ystanes, I.Å. Strønen (eds.), The Social Life of Economic

Inequalities in Contemporary Latin America, Approaches to Social

Inequality and Difference, DOI 10.1007/978-3-319-61536-3_10 
The inhabitants of Majes come from different places, with various cultural, educational and economic backgrounds, and this diversity is emphasized interchangeably as a problem or strength.

In this chapter, I will discuss how Majes has emerged as 'a place of opportunities' through relations of capital and labour, in which inequality is also (re-)produced. ${ }^{1}$ The analysis is inspired by Bear et al. (2015), who express an interest in 'how inequality emerges from heterogeneous processes through which people, labour, sentiments, plants, animals, and lifeways are converted into resources for various projects of production'. I argue that economic inequalities, which are embedded in differences based on conceptions of race and gender, have increased during the past three decades of neoliberalism in Peru, where working conditions have worsened and informality, precarity and uncertainty prevail. I refer to neoliberalism as a set of policies and practices inspired by a political ideology according to which human well-being can best be advanced by liberating individual entrepreneurial freedoms and skills within an institutional framework that secures private property rights, free markets and free trade (Harvey 2005). The neoliberal paradigm relies on individuals who are induced to self-manage according to market principles of discipline, efficiency and competiveness (Ong 2006). However, for most workers and farmers, the neoliberal 'freedoms' have implied increased vulnerability and uncertainty. I will therefore explore how families experience debt and loss, yet continue struggling to get ahead in a precarious informal economy.

In Latin America, including Peru, working conditions for the poor have always been precarious (Millar 2014). The analytical concepts have changed, however; the term citizenship had largely replaced class as a means of analysing the political struggles of the poor in Latin America at the beginning of this century (Roberts 2004). I argue that the inequalities in Majes are manifest in structures of gender, ideas of race and culture and emergent class relationships, understood as bundles of 'unstable, uneven, contradictory and antagonistic relational interdependences' (Kalb 2015:14). However, these class formations, which are emerging from the unequal conversions of humans into resources, are not always complete, consistent or coherent (Bear et al. 2015). I will show how inequality is embedded in the intersections of class, gender and race and argue that these differences did not diminish with the so-called Pink Tide that Ollanta Humala (2011-2016) barely flirted with (see Introduction (Chap. 1) of this volume), just as they did not disappear with the left-wing reforms in the 1970s. 


\section{The Diversity of Majes: Ambivalent Racism}

The population of Majes consists of people from all over Peru. The majority of the recent migrants come from the impoverished rural Andean highlands: mostly from the south, but also from central Peru. The southern and central highlands constitute the main areas of what has been called 'deep Peru' (Perú profundo). The expression 'deep Peru' was first used by the Peruvian historian Basadre who in 1943 distinguished between 'two Perus': the state (pais legal, or legal country) and the nation composed by its people (pais profundo, or deep country). While Basadre referred to all sectors of the population, and not only indigenous culture, later usages of the phrase have changed and now it has come to mean 'the historical roots of Indianness as a component of Peru's sense of nationhood' (Mayer 1992:192). In his report from a massacre in the south-central highlands in 1983, during the war between the guerrillas and the armed forces, the Peruvian author Mario Vargas Llosa used the phrase to describe a country divided in space and time. One part was the official Peru and the other profound, consisting of the indigenous population: an 'Indian Peru' that was economically depressed, 'miserable' and 'primitive' (Mayer 1992:193). In an article in New York Times, Vargas Llosa described the village where the massacre happened: 'At these altitudes, the land is poor, the isolation is almost absolute, and the customs are archaic' (Vargas Llosa 1983). More than three decades have passed, but the phrase 'deep Peru' is still used in Majes and the rest of (mostly coastal and urban) Peru to describe the indigenous character of people in the Andean highlands, and racist connotations are still prevalent.

However, since most people have family and connections to the indigenous Andes, racist attitudes are highly ambivalent. When talking to people in Majes-whether they were municipal workers, state engineers, farmers or businesspeople-many complained to me that the people here 'have no [local] cultural identity', because 'they come from all places and they all come with their own culture'. Some went on to explain that there is 'a struggle of cultures', 'a clash of cultures' or 'a crossing of cultures and races'. A more positive comment was that 'we drink from all the cultural sources'. In his book on the local history of Majes, Edgar Zamalloa writes: 'the population of Majes is made up of men of all the bloods [sangres], coming from all parts of deep Peru, who have come and/or have brought or are introducing dances and customs from their different places of origin' (Zamalloa 2013:347). Zamalloa is also the author of the Majes hymn, 
Himno de Majes, which has provided the phrase that was chosen the official slogan of the district municipality of Majes: Con la fuerza de todas las sangres, 'With the force of all the bloods'. Coming from the highland region of Apurímac, Zamalloa was inspired by his compatriot José María Arguedas, the anthropologist who authored the novel Todas las sangres ('All the bloods'), a title that refers to the cultural diversity of Peru. From the colonial era, differences in culture and class have been-and are still-racialised in Peru, and this is reflected in the (often used) plural form of blood.

Nevertheless, ethnic and racialised categories are intrinsically linked to social class and place, which in practice means that a person from a Quechua-speaking rural community who moves to the city, acquires formal education, learns Spanish and adopts an urban lifestyle is no longer considered to be 'indigenous' but mestizo (van den Berghe and Primov 1977). Class and education is translated into economic and social capital and can make a person to be considered 'socially white', given the geographical construction of race, where the coastal line is 'white' and the highlands are indigenous (de la Cadena 2000). In other words, racialised categories are fluid and can be changed through social and geographical mobility. These categories can also vary with gender, however, as women are often considered to be more 'Indian' (de la Cadena 1991). In Majes, this is mostly reflected in clothing and language, as women from the highlands often dress in traditional skirts and hats and sometimes talk in Quechua or Aymara among each other at the marketplace, while men tend to dress in urban clothes and only speak in Spanish.

The precarity and uncertainties that have followed neoliberal deregulations affect everyone, yet in different degrees: those who have historically been discriminated against based on their ethnicity and/or gender, and who always have had less access to resources and social capital, are also those who suffer most from the new kinds of precarity in labour and farming. In today's Majes, inequalities are manifest in access to water, land and capital and also in the ability to plan a future, which is a privilege that financial security allows.

\section{'Peasant, the Landlord Will No Longer Eat Your Poverty': Agrarian Reform}

In 1971, the military left-wing government of Juan Velasco Alvarado (1968-1975) started the execution of MIP: the Condoroma Dam was built 4158 meters above sea level, from which water is released downriver 
and led into a system of 101 kilometres of tunnels and canals through Colca Valley. In Majes, the water is led into a network of irrigation canals crisscrossing the arid pampa at 1000 m.a.s.l., where a stable and warm climate all year round secures good conditions for agriculture. MIP aimed to create economic growth based on agricultural and industrial production, and to foster development for the whole region. After the water arrived to the pampa of Majes in the end of 1982, the first settlers (colonos) started to work on their land. In the first group, there were 592 colonos who had been selected by draw according to the different categories they belonged to: smallholding farmers, landless peasants, agricultural workers and professionals - mostly agronomists, but also doctors, lawyers and engineers (Zamalloa 2013). One engineer who had worked there for 30 years, called the Majes project a populismo culto, which can mean a 'cultured', 'learned' or 'educated' populism, because of these different categories. Therefore, he said, here we have all kinds of people; the irrigation project was not only for the poor, but also for people of all professions, and from all parts of the country. By calling it culto, he alluded to the general praise of formal education in Peru, which elevates people in the hierarchies of class and race. In MIP, all settlers got an equal start: each got the opportunity to buy 5 hectares of land, which was considered a basic family unit, with a subsidised loan from the state-owned Agrarian Bank (Zamalloa 2013). Today there are 2600 farms in the irrigated areas of Majes.

MIP was implemented soon after the 1969 agrarian reform and became part of Velasco's endeavour to bring Peru out of feudalism and poverty and into an era of equality and progress. Before 1969, 3.9 per cent of the population controlled 56 per cent of the land, most of it in the form of large holdings (Seligmann 1995). In 1968, Velasco's 'Revolutionary Government of the Armed Forces' (Gobierno Revolucionario de las Fuerzas Armadas) started to nationalise the land, water, industry and banks. By using the power of popular mobilisation, the plan was to defeat the oligarchy, to reduce the power of the landowning elites and increase economic productivity. Cant (2012) shows how posters were used in mobilising the peasants: "Slogans such as "Land without masters" and "We are free, the revolution is giving us land" put forth an emancipatory vision of a "new Peru", articulating the government's aspirations towards a more equal and integrated society' (Cant 2012:3). In his speech to introduce the agrarian reform on the Day of the Peasant, 24 June 1969, Velasco talked about forging a better nation that would be the owner of its own destiny, with justice and freedom. He famously concluded by saying: 'Peasant, the landlord 
will no longer eat your poverty!' (Velasco 1969). Between 1969 and 1974, 175,000 families received 4.5 million hectares of land (Cant 2012:4). In less than a decade, the land reform succeeded in ending the dominant power of the hacendados and introducing a system of cooperative farms (Collier 1978). The Velasco regime believed that they could uproot racial discrimination by destroying the power of the landed oligarchy, but they were unable to achieve economic equality and a respect for ethnic differences at the same time (Seligmann 1995). Velasco officially replaced the ethnic and racial term indio (Indian) by the class-related term campesino (peasant), but peasants are still discriminated against in today's Peru.

However, the new agrarian cooperatives, which were largely managed by technocrats and bureaucrats, encountered huge problems. State control led to corruption, clientelistic relationships and internal conflicts (Hunefeldt 1997). Lack of planning, training and technical support for the farmers were some of the reasons that the reform mainly failed (Rénique 1991). The shortcomings of the reform, in addition to rural poverty and expectations of a better life in the cities, led to a massive increase in migration from the highlands to the urban coast. A major part of the current population in Majes come from the regions of Puno, Cusco and Apurimac, where the agrarian reform had profound effects on socioeconomic relations. In the Colca Valley, however, the peasants were never dominated by the haciendas (Guillet 1992), yet many have migrated to Majes because of poverty and lack of opportunities, and more recently due to climate change, experienced as seasonal instability and water scarcity (Stensrud 2015).

\section{La lex Del CHINITO: The Neoliberal Turn}

Well, now we have the law of el chinito [Alberto Fujimori] ${ }^{2}$ : the law of supply and demand $[\ldots]$, so the market manages itself. When the production is high - boom! - [the price] falls. [...] So then there is an atrocious loss for the farmer.

The farmer who told me about the 'law of the chinito' arrived in Majes in 1983. Since then, he has built a dairy farm with 20 cows, and has been combining the cultivation of alfalfa fodder with various other crops. As many other farmers in Majes, he describes the production of food as a lottery, because one never knows if one will win or lose until it is time to sell the products. Therefore, he has kept the dairy production as a secure base: 
although milk does not pay well, it is a safe income. Dairy farming has been the main economic activity in Majes since the start, but it is dominated by the monopsony of the Gloria Group that buys the milk from the farmers.

The turn towards neoliberal economic policies started with General Morales Bermúdez (1975-1980), who replaced Velasco in a coup d'état, and was continued under President Belaúnde Terry (1980-1985). In his first presidency, Alan García (1985-1990) tried to reverse the liberalization process through what was termed a 'heterodox' economic policy. García ambitiously proposed social reform for the poor majority, without wanting to alienate the business elites. The result was a deep economic and social crisis, with soaring inflation, devaluation, rising unemployment, shortages of staples and malnutrition (Klarén 2000). In 1990, Alberto Fujimori, a populist with no affiliation to any traditional political party or to the white oligarchy, was elected president. He quickly established an extreme variant of the structural adjustment that was advocated by the "Washington consensus' and the World Bank (Gonzales de Olarte 1993). The so-called Fuji shock consisted in radical austerity measures: higher interest rates and taxes and a slashing of price subsidies and social spending. The shock was followed by deregulation of markets, massive privatisation and incentives for international investment (Klarén 2000; Crabtree 2002). In 1991, President Fujimori issued a 'labour flexibilisation' decree, which significantly altered the laws regulating job security and the right to organise (Klarén 2000). Since then, the majority of workers in Peru are informally employed and thus deprived of benefits and protection. Simultaneously, a strong ideology of entrepreneurship as the way out of poverty and towards progress has been fostered (see also Ødegaard, Chap. 8 in this book).

In agrarian policy, the neoliberal restructuring in the 1990s entailed a total reversal of the agrarian reform. All forms of subsidies to farmers were cancelled, and the last vestiges of protectionist agrarian laws were removed, allowing unlimited private property (Mayer 2009). The 1995 Land Law (Ley de Tierras) promoted the titling of individual land ownership, abolished the previous upper limits on personal landholding and allowed the state to sell land currently in public ownership. The new law opened the way to the capitalisation of agriculture by enabling titleholders to raise mortgages (Crabtree 2002). This deregulation had long-term consequences, and in Majes it has led to a dramatic increase in the price of land. Peasants from the highlands can no longer afford to buy land and are reduced to rural proletarians working for landowners and the large-scale 
agribusiness that was welcomed in Majes in the 1990s. In 1998, a land property of 1288 hectares called Pampa Baja, where new irrigation infrastructure just had been installed, was sold to a private company. Today, the Pampa Baja Group has employed 2000 workers and produces fruit for export. ${ }^{3}$ Fujimori's structural adjustment also affected farmers' ability to plan cultivation of food and future incomes. Among his first moves was to scrap price controls, allowing these to be set by market forces. He also closed down the institution that controlled food imports and eliminated the Agrarian Bank as a source of subsidised credit to producers (Crabtree 2002). Private lenders charge very high interest rates when they lend money to small-scale farmers due to the high risk involved.

The election of Alejandro Toledo as president in 2001 was seen as a return to democracy after Fujimori's authoritarian rule. Nevertheless, in spite of promises about ending privatisation and creating employment, he continued on the neoliberal road and so did Alan García in his second presidency (2006-2011). Toledo started the work on a Free Trade Agreement with the USA, and when García signed the agreement in 2007, he declared that this was a great day for democracy, social justice and freedom. Earlier that year, however, García had made social protests and strikes illegal, accusing the opponents of private investment and free trade-labour unions and indigenous movements-for obstructing progress due to old ideologies, laziness and inertia (García Pérez 2007).

During the presidential election campaigns in 2006 and 2011, Ollanta Humala, who became leader of the Nationalist party (Partido Nacionalista Peruano) in 2005, promised to fight against privatisation and imperialism, decrease the gap between rich and poor and work for 'social inclusion'. Humala, who is son of a Quechua-speaking communist lawyer and has great admiration for Velasco, got massive support, especially among indigenous peasants and working poor in the central and southern highlands. This support was a clear expression of popular anti-neoliberal sentiments, and Humala's candidature is associated with the 'Pink Tide' in South America. However, after winning the election in 2011, he did not keep his promise of a 'great transformation'. He appointed neoliberal technocrats from the previous administration and maintained the neoliberal policies favouring private investment (Poole and Rénique 2012). When MajesSiguas II, the second phase of the irrigation project, was inaugurated in 2014, Humala promised that water would never be privatised. Yet, he allowed the private consortium Angostura-Siguas to get the concession for Majes-Siguas II. Farmers in MIP are afraid that the consortium will 
increase the water tariffs in order to recover its investments, and that this concession will benefit large agribusiness corporations and not small- and medium-scale farmers. In the presidential elections of 2016, the left-wing candidate Veronica Mendoza got huge support from people in the highlands who had also voted for Humala. She did not enter the second round, however, which was fought between Keiko Fujimori, the daughter of Fujimori, and Pedro Pablo Kuczynski, a white man with extensive experience from banking and mining industry, who was minister of energy and mining under Belaúnde and minister of economy and finance under Toledo. Hence, the election of Kuczynski is seen as a victory for continued neoliberalism in Peru.

\section{'People Suffer Here Also': Children of Settlers}

The very first settler arrived in Majes in October 1982, two months before the water came, and he has seen many of his fellow farmers lose their land: 'Of the first group of settlers, now there is only half left'. When I interviewed him about agriculture in Majes, he talked about the volatile prices of the free market and the farmers' dependency of the intermediary merchants:

The prices always fall, when everyone sow potatoes, the prices fall $[\ldots]$ In 2009 , there was a good harvest of ají paprika; then the price fell from 2,80 USD per kilo to 0,80 cents. The same happened with the onions [...] There is more risk now than 30 years ago; now there is free market. Earlier we had stable prices, but Fujimori made free market. [...] The financial institutions that give loans take a lot of interests; 18 per cent and until 30 per cent! Some get indebted because the intermediaries don't pay the products that they have bought and taken away. (17 February 2014)

Among the farmers in Majes, Velasco is remembered as a hero, both for ending the power of the landowning oligarchy and for starting the construction of MIP. Fujimori, on the other hand, is given much of the blame for everything that went wrong because of the 'free market'.

José is the son of one of the settlers who lost his land because of debt. ${ }^{4}$ José's grandparents were very poor when they lived in his home village; they only had a tiny piece of land and a couple of cows, and they mostly worked as labourers on the land of others. Their nine children went to Arequipa city very young to work and go to school. When the Majes project opened, all the siblings registered and four brothers got farms: 
José's father and three uncles. They were all dreaming about coming here and changing their lives; 'to have another way of being'. The brothers were always united and worked together, they told me. Instead of hiring help like others did, they helped each other. However, Josés father had bad luck and was not able to pay his loan to the bank. The debt accumulated and he was forced to sell the farm. José's three uncles still have their farms, and sometimes José works with his cousins in the fields; he helps to rent machinery, to buy seeds and to sell the harvest. To make a living, José has worked in all kinds of jobs in different public offices, mainly as a driver or assistant, on temporary contracts. Steady employment is hard to find, and many people try to start businesses of their own. José and his wife bought a mini-bus on credit with the intention of making money in the transport business. When they finally got permission to work on one of the bus routes in Majes, however, they soon realised that the income was not enough to pay the debt and have a profitable business. They ended up selling the car.

As the daughter of a farmer who came with the third group of settlers and later got into debt, Martina has first-hand experience of the tensions and sufferings that debt creates. 'People suffer here also. Not everyone has access to credits and capital to work, they have debts', she said. She came from Colca Valley as a ten-year-old in 1990, when her parents settled into the new farm, and she learned early the value of hard work. Her father was not only a farmer but also a merchant who sold groceries from a market stall in Villa El Pedregal. When his potato harvest failed three times in a row and the prices fell, he got caught up in debt. He is still carrying these debts until today. 'The interests are very high; you pay off and you pay off, but you never finish paying the debt', Martina said. When she was 17 or 18 years old, her father gathered his eight children to tell them that they should not expect any inheritance, but should take the opportunity to study. 'This stayed in my mind, and therefore I never expected anything from my parents', Martina told me.

Today, she is the owner of a market stall in Villa El Pedregal where she sells juice and sandwiches and also CDs and DVDs with popular Peruvian music. Martina started her business ten years ago, without any bank loans and credits, and it has grown little by little. She observes how all farmers and merchants work with credits nowadays; the merchants even take out credits from two or three banks. 'It is terrible to enter into debt', she said, remembering how she used to help her dad in his business and how she took part in his constant worries: 'it is stressful!' 
As I had been living in Colca Valley, I told Martina that people there think that the people in Majes are rich. She agreed, since she had experienced the same attitudes in Colca: 'Yes, there they think that we have money. I see how they look at me: "she got money, therefore she is aloof and does not talk to us" ... and I'm there all shy! They don't know that we also suffer. I live off my work!'.

Apparently, the fact that Martina lives in Majes with its booming economy, and that she works in her own business, make people in her home village assume that she believes herself to be 'better' than them. She certainly has climbed economically and socially according to the dominant hierarchy of class and race: she is no longer a peasant living in the highlands, but a businesswoman who lives near the coast. Within the marketplace in Majes, however, her small fruit juice stall, where she works long days and where her children do their homework after school, is one of the least profitable businesses compared to the meat and grocery vendors or the large-scale merchants (Photo 10.1).

In an upcoming expansion of the irrigation project-Majes-Siguas II-38,500 new hectares of land in the adjacent desert of Siguas will be

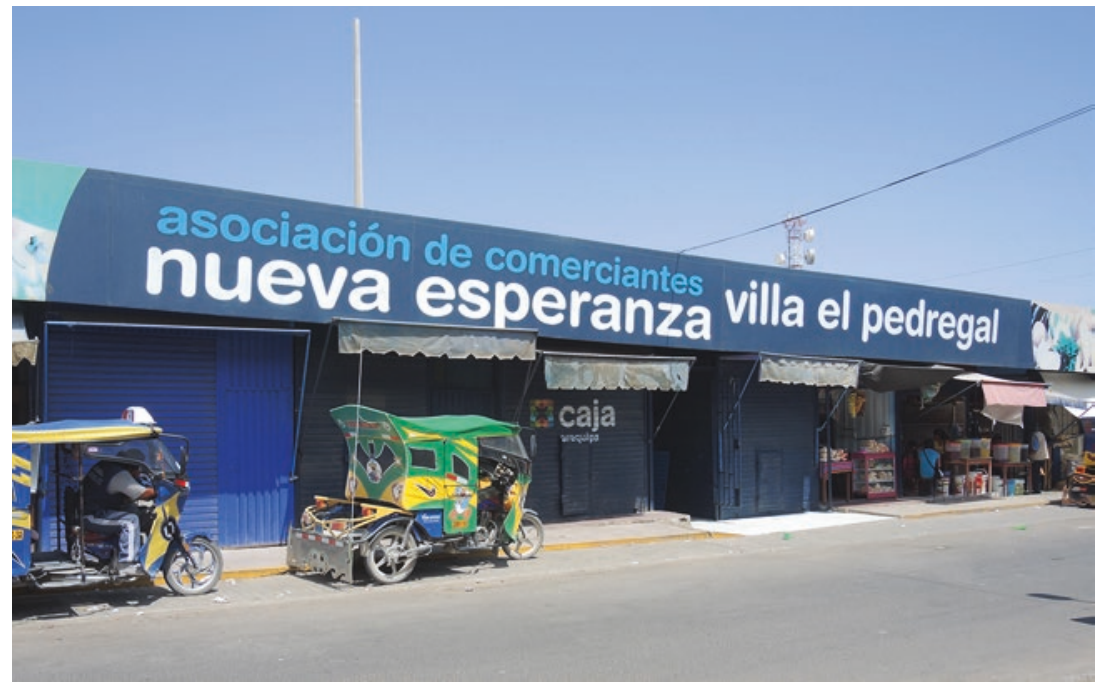

Photo 10.1 'New Hope' (Nueva Esperanza) is the name of one the marketplaces in Villa El Pedregal and the name of the association of vendors and merchants (asociación de comerciantes) who work there (Photo by the author) 
irrigated. However, the land will be sold in large units of 200, 500 and 1000 hectares and not in five-hectare family units as in the first phase of MIP. Hence, there will not be any opportunities for the children of farmers to buy land, and people fear the dominance of large-scale agribusiness. Martina, however, was carefully optimistic about her children's opportunities in the future:

We will grow here. As there is industrialisation all over, it will be the same here. In Siguas there will be companies like DANPER and Pampa Baja, and we will be employed in those companies. That is why I want my children to study and become professionals and technicians (profesionales y técnicos), so that they will not be only [unskilled] labourers (peones).

Most people still think that education is important for social mobility, although it is no guarantee to get formal and steady employment, which has become scarcer since the 1990s. Education as a means of ending poverty, social exclusion and 'underdevelopment' was for a long time a national project embraced by all social classes in Peru (Degregori 2008). Until the mid-twentieth century, there was a strong belief in the power of education to improve the 'Indians' racially, and the hegemonic acceptance of legitimate social hierarchies based on levels of formal education has prevailed until today (De la Cadena 2000). However, as part of neoliberal reform, state support to public education has decreased since the end of the 1970s (Degregori 2008), and the state's strategy for ending poverty and achieving development has gradually shifted its focus from education to the importance of entrepreneurship (see also Ødegaard, Chap. 8 in this book). Individuals are encouraged by state institutions and NGOs to start their own micro-enterprise in order to get ahead in life. In most of the life stories that I heard in Majes, men and women expressed great pride in being self-made. In the later years, however, the competition to get jobs, a successful business and a place to live have increased. The farmers' children not only compete against each other but also against the new migrants that come in search of a livelihood and a future.

\section{'We Should Make an EfFort': SQuatters in the Desert}

Today, the majority of the population no longer consists of farmers: new people move in every day in search of work, business and land. According to the census of 2005, there were 35,334 inhabitants in Majes, while in 2014 
the municipality considered the number of inhabitants to be somewhere between 100,000 and 120,000. The engineers who planned MIP originally designed urban centres and infrastructure for 40,000 inhabitants. Today's population is spreading out in the surrounding desert, where there is no infrastructure for the provision of water and electricity. The majority make a living as land labourers or factory workers or work in mechanical workshops or in the service sector. Many are self-employed as taxi drivers or food-anddrink vendors in the streets, in the marketplace or in small restaurants.

These migrants are not only searching for work but also a piece of land to build a house of their own. Earlier, the state distributed land lots at subsidised prices, but today many of these lots are sold expensively. Alternatively, those without money can 'invade' a piece of empty land and claim ownership. If a person can prove that she/he has built a house (many use straw mats, which is the cheapest material) and has lived on a lot for a certain amount of time-this is called 'possession' (posesion)she/he can apply for the right to buy the land and get a formal title deed. In March 2014, the sub-director of the Municipal Office of Formalisation said that they had 20,000 case files in the office. Many of these have already paid their properties, and some have contracts, while others have yet to present documentation to support their case. In order to formalise ownership, obtain title deeds and eventually get access to water pipes, electricity, roads and other infrastructure, it is common to organise in neighbourhood associations. Meanwhile, people buy potable water from trucks that come once a week, or they boil water from the irrigation canals. Many of the recently arrived migrants join squatter groups, called 'invasion groups' (grupos de invasión), to occupy desert land collectively in and around Ciudad Majes. This practice has led to a lot of problems, however, since some of the leaders of these squatter groups have become land traffickers. The situation was often described as chaotic and corrupt, with many illegal transactions, conflicts and violence.

One of the women that live in the desert is Lucía, who was 38 years old in 2014. She was born into an Aymara-speaking peasant family in the highlands of Puno, and as a seven-year-old, she was sent to an aunt in Arequipa city. Lucía started working as a servant in the house of a middle-class family, but she did not know how much she earned because her aunt took the money. During the next ten years, she went back and forth between Arequipa and Puno, and then to the coastal city Tacna. She worked as a domestic servant for several families and experienced different degrees of exploitation. When she was 14 years old, an elderly man working at the 
marketplace in Tacna taught her how to read and write. At the age of 19 she got pregnant with a man who was also from Puno. They married and moved to Villa El Pedregal. He would not allow her to work, however, and she had to stay home in their rented room, taking care of their four children. After six years, she convinced her husband that she had the right to an education, and she studied hairdressing. She also started to work as a shop assistant. After 14 years of marriage, she left him.

Lucía dreamt about having her own grocery shop, and she joined an association of vendors who collectively invaded a piece of empty land. The goal was to obtain ownership to the land and to start their own marketplace, in which all participants would have a shop of their own. Although the leaders told them that the land was empty, they soon found out that another group had already invaded it, and that they were the second invaders. Still, the leaders gave all of them a kiosk of a few square meters to have a place to work and make their business. There were 600 stalls, and as some vendors brought their partners, children or cousins for support, they were more than a thousand people in total. They all paid their fees to the association, built kiosks and defended their place. The first invaders attacked them with homemade bombs, exploding bottles, and Lucía was very scared. She wanted to escape, but the others wouldn't let her go: 'You just have to endure', they told her, 'we do this to have a place to work'. And since she already had paid 200 soles, ${ }^{5}$ she stayed. Some vendors started selling groceries there. Everyone had to attend the meetings, do collective work and pay the fees for the lawyer and other expenses. The leaders handled everything, and 'we were the stupid ones who followed them'. She stayed for two years before she left. Two months later, she heard that the police had evicted the ones that stayed. Everything was destroyed and the vendors had lost all their supplies.

Although Lucía studied hairdressing, she did not have the courage to exercise it at first. When she at last started working in a hair salon and received payment for her first haircuts, she finally gained self-confidence. She rented a chair in a salon, and she got regular clients. But when she had a baby with her second husband, the others complained that the baby disturbed their work. Therefore, shortly before I met her, she decided to rent a locale where she would run her own hair salon. She got a credit loan from a bank to buy equipment, and she planned to pay it back in two years. 'Everything that I have, I have achieved it by myself', she said, and continued: 'I don't know what awaits me ahead ..., but everything has a solution'. 
In 2013, she married her second husband, Alfredo, who is also from Puno and works as a night watchman, in addition to occasionally driving a pirate taxi. His first wife stayed in their house in one of the new neighbourhoods in the desert, and Alfredo moved in with Lucía in a rented room in Villa El Pedregal. They soon decided to build a house of their own on a land lot in the desert that Lucía had acquired when the state was handing out subsidized lots and that she had been paying little by little. They built the house together, one room at a time, and today they live there with their son and Lucía's children from her first marriage. There are no roads, water pipes or electricity in the area. Once a week, a truck brings water, which they store in plastic containers. At night, they light candles so that the children can do their homework for school.

When a squatter group tried to invade the area, the people living there decided to organise in a neighbourhood association, and Alfredo was elected leader. The purpose is to defend their land and to obtain access to electricity and water. They also wish to have a marketplace and a primary school. They have meetings once a month on Sunday mornings, since most of the neighbourhood's residents are agricultural workers and Sunday is their only day off. However, only a few of the property owners actually live there because of the lacking infrastructure. Alfredo tried to convince more people to build their houses, in order to put pressure on the municipality. He was constantly knocking on doors in the municipality in order to obtain electricity and water. Lucía supported him: 'we should make an effort; if one doesn't insist, nothing happens'.

Like Martina, Lucía had gained economic and social mobility by her own work and effort, in spite of her lack of formal education and the other hindrances that life had offered her. Instead of becoming a peasant, a domestic worker or a subdued housewife, she had made an effort to gain skills, work experience and finally her own business. In this sense, shejust like Martina-embodies the entrepreneurial and neoliberal ideal that the government envisions: that people can come out of poverty through individual entrepreneurship. Neither Martina nor Lucía wore traditional clothing from their home places but dressed and talked Spanish like urban mestizo women. Both had moved from their rural communities as small children and had lived most part of their lives in cities and/or in MIP. However, for every business that succeeds, there are many that fail. Martina and Lucía were very aware of the danger of working with credit and entering into debt, especially in a precarious economy where the competition from other vendors and micro-businesses are increasing every day. 


\section{Emerging Inequalities: 'Race’, Class and Gender}

After 30 years of neoliberal policies, the processes of differentiation in Majes are becoming evident. With the broad availability of expensive credit loans, and production based on uncertain anticipations of the fluctuating product prices, a few farmers have prospered and expanded their farms, while others have drowned in debt. The second generation of the first farmers who settled in MIP often work on temporary contracts in exportoriented agribusiness factories, in the service sector, transport, construction sites, or in state and municipal institutions. As job security is practically non-existent and the informal economy is growing, many young people try their luck as micro-entrepreneurs. Most of the new migrants, who come from all over the country, but mostly from the southern highlands, work as land labourers (peones) on a day-to-day basis. Each morning, they go very early to a place behind the main market in Villa El Pedregal, where the farmers come and take the workers they need to their farms. They are usually paid 50 soles a day or 60-70 soles if it is specialised work. Hence, there are days when they earn money and days when they don't (Photo 10.2). Many of the new migrants also make a livelihood by selling food on the streets, but they are regularly removed by the municipal agents who do not tolerate vendors without a municipal license. As the population grows, the social inequalities and structures of prejudice, stigmatisation and discrimination that predominate in Peru are also reinforced in Majes.

Jorge is one of the few first settlers who have been economically successful. He has tripled the size of his farm where he cultivates grapes and avocados for export. As most of the successful farmers, however, he did not have a background as a poor peasant from the highlands. He was originally from the coastal city of Tacna and was educated as an agronomist, and had thus the social and cultural capital that provide an advantage in the Peruvian social and racial hierarchy based on geography and education. Moreover, he and other farmers with similar interests got organised, and he is today the elected president of the Avocado Association. In an interview, he talked about the people coming to Majes in search of work, who he hires as day labourers on his farm: 'The people who live in the high parts where there is no work, where there is hunger; the 'deep Peru' as we call it, where the government does not come; those people come here, and the next day they have work, because here there is a lot of work'. With this statement, he not only confirmed the stereotypical and stigmatised image 


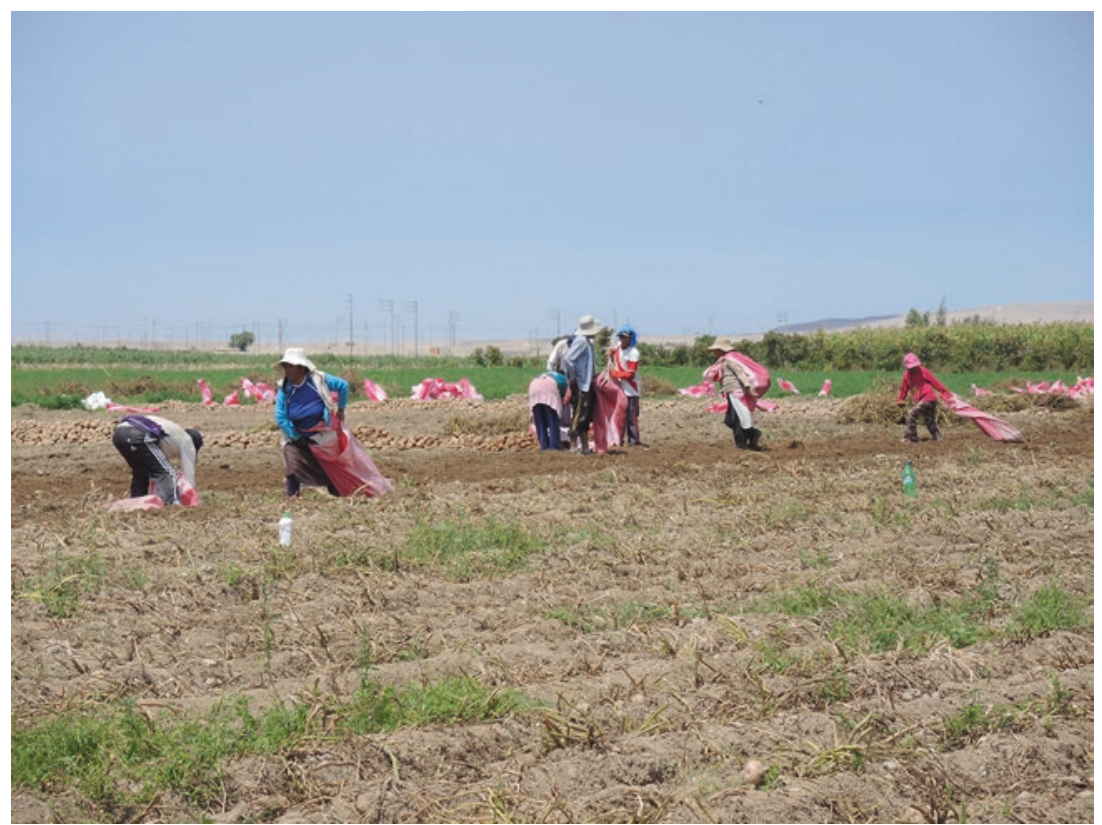

Photo 10.2 Day labourers (peones) harvesting potatoes on the land of a settler farmer (colono) (Photo by the author)

that people on the coast have of the highlands, but he also implied that these people are lucky to get work as land labourers.

It was often pointed out to me that 'the majority' of the population in Majes were people from Puno (puneños). In Villa El Pedregal, most of the merchants and market vendors are puneños, and the women are especially easy to recognise because of their characteristic skirts and bowler hats. The leader of the 'Association of Residents from Puno' roughly estimated that there are approximately 50,000 puneños in Majes because of the job opportunities. He said that the majority of the population in most Peruvian cities are from Puno: 'we have always been characterized by our presence', he said. He continued: 'The puneños stick out (son sobresalientes), mostly because of the force of labour that they put in: you will never find a worker from Puno who is lazy; el puneño is always a hard worker (de chamba)'. People from Puno, as in the rest of the Andes, are proud of being good 
workers; to be able to work hard is a virtue. However, success in economic activities, and more importantly, a visible display of material wealth, is not always appreciated by others. The puneños have brought their customs from Puno, and every year they celebrate the Virgin of Candelaria with famous splendour and colourful dances (see also Stensrud 2016). I heard others comment that it looks more like a display of riches and of the ones with most money than a devotion of the Virgin'. In other contexts, I heard comments that reflected the racist attitudes against people from the highlands, such as 'be careful with the puneños'. One informant told me: 'the puneños are all over: they get many children, like rabbits. They multiply and need space'.

Since the creation of the municipal administration in 1983, the mayors of Majes have been keen to create and promote symbolic events, objects and performances - monuments, a coat of arms, a flag, songs and poemsthat show the uniqueness of Majes and that simultaneously evoke patriotic feelings in the local population, feelings that should unite a diversified population (Zamalloa 2013; Stensrud 2016). These objects—as well as the dominant narratives about the creation of MIP-emphasize and promote a mestizo identity: neither indigenous nor Spanish (or white elite), but a mix that has become the new generic racial category of Peruvian national identity. The narratives are, however, highly gendered: the settlers who are praised for their hard work and sacrifice in speeches, poems, songs and monuments are represented as male mestizo pioneers and brave frontier men. Zamalloa's Himno de Majes, which was declared the official hymn of the district in 2003, says: 'Great men are your strength, ranchers and farmers, who are cultivating the furrow of progress...'. At the entrance of Villa El Pedregal you are met by the impressive statue of General Velasco, who is considered the founder of MIP. In Villa El Pedregal, the monument of the settler, el Monumento al Colono, which is a statue of a farmer holding a milk can, has a central place. Women, on the other hand, are included in the Cow Monument, Monumento a la Vaca: a statue of a cow being handmilked by a milkmaid. Women are mainly celebrated on Mothers' Day-in their capacity as mothers, wives, caretakers and nurturers-and in beauty contests, where the winner is given the title 'Queen of Majes'. Some people commented that the queen always is a 'daughter of a settler, someone of economic resources', and never a girl from the highlands. Hard-working businesswomen, like Martina and Lucía, are, however, seldom celebrated in public events. 


\section{CONCLUSION}

Majes is portrayed as the land of milk and honey, a place of hope and progress that is bustling with opportunities of jobs and business. On the one hand, there is a desire and pressure to transform farmers into businessmen, yet on the other hand, there are processes of dispossession, proletarisation and precariasation going on, and social inequality is increasing. In 1983, all the settlers started with equal five-hectare farms in a project to create economic growth and 'progress', through the domestication of desert, water, seeds, animals and human labour. Thirty years later, a few have prospered and bought new land, while many have been forced to sell their farms. The majority keep working, hoping to make profit and praying that the prices will not fall. Today, it is not the hacendados that 'eat' the farmers' poverty, but the banks and the agro-corporations. Among the second generation, that is, the children of settlers, there are differences between those who have completed higher education to become engineers or other professionals and those who work in factories, construction, transport and the service sector. Many have started their own micro-enterprises: mechanical workshops, beauty salons, restaurants or grocery shops. Most of the recently arrived migrants are day-to-day land labourers, taxi drivers and vendors in markets and streets, with or without formal licenses. Formal employment is scarce, working conditions have worsened since the deregulations in the 1990s, and informality, precarity and uncertainty prevail.

Farmers and working poor are being transformed into precarious entrepreneurs, highland peasants are transformed into land labourers, and unsuccessful entrepreneurs are transformed into street vendors or factory workers on insecure contracts. The ideal citizen of Majes is a male mestizo farmer with an entrepreneurial spirit who has gained economic success through hard work and the taking of risks. Migrants are portrayed as coming from abject poverty and as they are used to a miserable condition, they should be content with finding work as day-to-day labourers. Women are publicly celebrated as mothers and housewives, while their reality as hard-working farmers, labourers and entrepreneurs is often disregarded. These inequalities did not disappear with the land reform, or with Toledo's promises of 'more work' or with Humala's 'social inclusion'. In fact, social inequalities will never disappear with top-down state reforms. On the one hand, political pressure from grass roots social movements is needed to obtain large-scale changes of economic structures. On the other hand, as inequalities, and the cultural attitudes that support them, are reinforced in daily life, they can only be altered through small-scale changes in everyday attitudes and practices. 


\section{Notes}

1. The research for this chapter has been funded by the European Research Council (grant no. 295843) and the Research Council of Norway (grant no. 222783). The analysis in this chapter is based on 13 months of ethnographic fieldwork in Colca and Majes in 2011, 2013 and 2014, and also informed by research in Cusco in the period 2001-2008.

2. Fujimori is son of Japanese immigrants and is colloquially called 'el Chino' by most Peruvians, who tend to call any person with a physical 'Asian' appearance chino/a, just as they have other nicknames that are informed by racialised stereotypes: indigenous cholos, dark-skinned negros, white gringos.

3. http://www.pampabaja.com/eng/main.php. Website accessed 6 September 2016.

4. All personal names have been anonymised.

5. In 2013 and 2014, l Peruvian Nuevo Sol PEN = 0,35 USD. PEN is referred to as $s o l$ in colloquial language and one sol $=100$ centavos.

\section{REFERENCES}

Bear, Laura, Karen Ho, Anna Tsing, and Sylvia Yanagisako. 2015. 'Gens: A Feminist Manifesto for the Study of Capitalism', Fieldsights-Theorising the Contemporary. Cultural Anthropology Online, March 30

Cant, Anna. 2012. 'Land for Those Who Work It': A Visual Analysis of Agrarian Reform Posters in Velasco's Peru. Journal of Latin American Studies 44: 1-37. Collier, David. 1978. Barriadas y élites: de Odría a Velasco. Lima: IEP.

Crabtree, John. 2002. The Impact of Neo-liberal Economics on Peruvian Peasant Agriculture in the 1990s. The Journal of Peasant Studies 29 (3-4): 131-161.

Degregori, Carlos I. 2008. Educación: La soga se rompe por el hilo más débil. LASA Forum 39 (3): 26-29.

De la Cadena, Marisol. 1991. 'Las mujeres son más indias': Etnicidad y género en una comunidad del Cusco. Revista Andina 9 (1): 7-29.

- 2000. Indigenous Mestizos: The Politics of Race and Culture in Cuzco, 1919-1991. Durham: Duke University Press.

García Pérez, Alan. 2007. El síndrome del perro del hortelano. El Comercio, 28 October

Gonzales de Olarte, Efrain. 1993. Economic Stabilization and Structural Adjustment Under Fujimori. Journal of Interamerican Studies and World Affairs 35 (2): $51-80$.

Guillet, David. 1992. Covering Ground: Communal Water Management and the State in the Peruvian Andes. Ann Arbor: University of Michigan Press.

Harvey, David. 2005. A Brief History of Neoliberalism. Oxford: Oxford University Press. 
Hunefeldt, Christine. 1997. The Rural Landscape and Changing Political Awareness. Enterprises, Agrarian Producers, and Peasant Communities, 1969-1994. Ch. 4. In The Peruvian Labyrinth: Polity, Society, Economy, ed. Maxwell A. Cameron and Philip Mauceri, 107-133. University Park: The Pennsylvania State University Press.

Kalb, Don. 2015. Introduction: Class and the New Anthropological Holism. In Anthropologies of Class. Power, Practice and Inequality, ed. James G. Carrier and Don Kalb. Cambridge: Cambridge University Press.

Klarén, Peter F. 2000. Peru: Society and Nationhood in the Andes. New York: Oxford University Press.

Mayer, Enrique. 1992. Peru in Deep Trouble: Mario Vargas Llosa's 'Inquest in the Andes' Reexamined. In Rereading Cultural Anthropology, ed. George E. Marcus, 181-219. Durham/London: Duke University Press.

. 2009. Ugly Stories of the Peruvian Agrarian Reform. Durham: Duke University Press.

Millar, Kathleen M. 2014. The Precarious Present: Wageless Labour and Disrupted Life in Rio de Janeiro, Brazil. Cultural Anthropology 29 (1): 32-53.

Ong, Aihwa. 2006. Neoliberalism as Exception: Mutations in Citizenship and Sovereignty. Durham: Duke University Press.

Poole, Deborah, and Gerardo Rénique. 2012. Peru: Humala Takes Off His Gloves. NACLA Report on the Americas, Spring Issue. http://nacla.org/ news $/ 2012 / 5 / 17 /$ peru-humala-takes-his-gloves. Accessed 8 Mar 2016.

Rénique, José Luís. 1991. Los sueños de la sierra. Cusco en el siglo XX. Lima: CEPES.

Roberts, Bryan R. 2004. From Marginality to Social Exclusion: From Laissez Faire to Pervasive Engagement, in 'From the Marginality of the 1960s to the 'New Poverty' of Today'. Latin American Research Review 39 (1): 195-197.

Seligmann, Linda J. 1995. Between Reform and Revolution. Political Struggles in the Peruvian Andes, 1969-1991. Stanford: Stanford University Press.

Stensrud, Astrid B. 2015. Raining in the Andes: Disrupted Seasonal and Hydrological Cycles. Chapter 3. In Waterworlds: Anthropology in Fluid Environments, ed. Kirsten Hastrup and Frida Hastrup, 75-92. New York: Berghahn Books.

—. 2016. 'We Are All Strangers Here:' Transforming Land and Making Identity in a Desert Boomtown. In Identity Destabilised: Living in an Overheated World, ed. T.H. Eriksen and E. Schober, 59-76. London: Pluto Press.

van den Berghe, Pierre L., and George Primov. 1977. Inequality in the Peruvian Andes: Class and Ethnicity in Cuzco. Columbia: University of Missouri Press.

Vargas Llosa, Mario. 1983. Inquest in the Andes. The New York Times, 31 July, translated by Edith Grossman. http://www.nytimes.com/1983/07/31/magazine/inquest-in-the-andes.html?pagewanted=all. Accessed 7 Mar 2017. 
Velasco Alvarado, Juan. 1969. Mensaje a la nación del presidente de la república del Perú, General Juan Velasco Alvarado sobre la reforma agraria, (Lima, 24 de junio de 1969). Estudios Internacionales de la Universidad de Chile 3 (11): 393-402. doi:10.5354/0719-3769.1969.18948.

Zamalloa, Ing. Edgar Bravo. 2013. Reseña Histórica del Distrito de Majes. Lima: Corporación Grafical

Open Access This chapter is licensed under the terms of the Creative Commons Attribution 4.0 International License (http://creativecommons.org/licenses/ by $/ 4.0 /$ ), which permits use, sharing, adaptation, distribution and reproduction in any medium or format, as long as you give appropriate credit to the original author(s) and the source, provide a link to the Creative Commons license and indicate if changes were made.

The images or other third party material in this chapter are included in the chapter's Creative Commons license, unless indicated otherwise in a credit line to the material. If material is not included in the chapter's Creative Commons license and your intended use is not permitted by statutory regulation or exceeds the permitted use, you will need to obtain permission directly from the copyright holder.

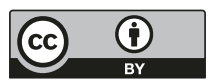

